\title{
HUBUNGAN PENGETAHUAN ORANG TUA TENTANG ISPA DENGAN KEJADIAN ISPA PADA BALITA DI DESA DAWUNGSARI KECAMATAN PEGANDON KABUPATEN KENDAL
}

\author{
Indah Wulaningsih ${ }^{1}$, Witri Hastuti ${ }^{2}$, Alfian Indra Pradana ${ }^{3}$ \\ 1. Stikes Karya Husada Semarang \\ 2. Stikes Karya Husada Semarang \\ 3. Stikes Karya Husada Semarang \\ E-mail:ns.indah@gmail.com
}

\begin{abstract}
Abstrak
Infeksi saluran pernafasan akut (ISPA) menurut World Health Organization (WHO) merupakan salah satu penyebab kematian tersering pada anak di negara berkembang. Tingginya angka penyakit ISPA pada balita, selain sering disebabkan karena kondisi kesehatan anak secara kongenital dan faktor lingkungan yang tidak sehat serta kurangnya pengetahuan mengenai ISPA.Tujuan penelitian ini untuk mengetahui hubungan pengetahuan orang tua tentang ISPA dengan kejadian ISPA pada balita di Desa Dawungsari Kecamatan Pegandon Kabupaten Kendal. Metode penelitian kuantitatif, rancangan penelitian deskriptif korelatif dengan desain cross-secctional. Sampel pada penelitian ini adalah 72 orang tua yang memiliki balita usia 1-5 tahun di Desa Dawung Sari dengan teknik pengambilan sampel purposive sampling. Data penelitian diperoleh dari kuesioner yang kemudian dilakukan uji validitas dan reliabilitas. Analisis data penelitian menggunakan uji chi square, diperoleh nilai $\rho$ value 0,031 $(<0,05)$. Sehingga ada hubungan yang signifikan antara pengetahuan orang tua tentang ISPA dengan kejadian ISPA pada balita di Desa Dawungsari Kecamatan Pegandon Kabupaten Kendal.
\end{abstract}

Kata Kunci : Balita; ISPA; Pengetahuan

\section{THE RELATIONSHIP BETWEEN PARENTAL KNOWLEDGE REGARDING ACUTE RESPIRATORY INFECTIONS (ARI) AND THE INCIDENCE OF ACUTE RESPIRATORY INFECTIONS (ARI) AMONG UNDER-FIVE AGE CHILDREN IN AREA OF DAWUNGSARI VILLAGE PEGANDON SUB-DISTRICT KENDAL REGENCY}

\begin{abstract}
According to the World Health Organization (WHO), Acute Respiratory Infection (ARI) is one of the most common causes of death among children in developing countries. High rates of Acute Respiratory Infection (ARI) disease in under five age children, is often caused by congenital child health conditions, unhealthy environmental factors and lack of knowledge about Acute Respiratory Infection (ARI). The purpose of this research is to know the relationship between parental knowledge regarding acute respiratory infections (ARI) and the incidence of Acute Respiratory Infections (ARI) among under-five age children in area of Dawungsari Village Pegandon Sub-District Kendal Regency. Quantitative research method and type or design of this research was descriptive correlative using the cross sectional approach. The research sample was 72 parents that have children in age 1 to 5 years old. The sampling technique was done by using purposive sampling technique. The data of this study were obtain from questionnaires. Analysis of research was used Chi-Square test. Based on the results, the statistical test using ChiSquare test obtained by $\rho$ value of $0.031(<0.05)$. With the result that, there is a significant the relationship between parental knowledge regarding Acute RespiratoryInfections (ARI) and the incidence of Acute Respiratory Infections (ARI) among under-five age children in area of Dawungsari Village Pegandon Sub-District Kendal Regency.
\end{abstract}

Keywords : Children under five year's old, Acute Respiratory Infection, Knowledge

Jurnal SMART Keperawatan Sekolah Tinggi Ilmu Kesehatan (STIKes) Karya Husada Semarang

www.stikesyahoedsmg.ac.id/ojs/index.php/sjkp(perawat) 


\section{Pendahuluan}

Infeksi saluran pernafasan akut (ISPA) menurut World Health Organization (WHO) tahun 2007, merupakan salah satu penyebab kematian tersering pada anak di negara berkembang. ISPA menyebabkan 4 dari 15 juta perkiraan kematian pada anak berusia lima tahun setiap tahunnya. Menurut data Profil Kesehatan Kabupaten Kendal Tahun 2014, di Kabupaten Kendal ISPA menempati ururtan pertama penyakit terbanyak sebesar 25,28\%. Berdasarkan data indeks penyakit pasien yang berobat di wilayah kerja Puskesmas Pegandon Kecamatan Pegandon Kabupaten Kendal tahun 2016, penyakit ISPA laki- laki dan perempuan usia 1-5 tahun sebanyak 2865 jiwa. Penyakit ISPA berada dalam urutan pertama penyakit yang ada di wilayah kerja Puskesmas Pegandon Kecamatan Pegandon Kabupaten Kendal.

WHO tahun 2007 menjelaskan bahwa infeksi saluran pernapasan akut (ISPA) adalah penyakit saluran pernapasan atas atau bawah, biasanya menular, yang dapat menimbulkan berbagai spektrum penyakit yang berkisar dari penyakit tanpa gejala atau infeksi ringan sampai penyakit yang parah dan mematikan. ISPA pada balita lebih berbahaya karena bentuk lidah pada anak lebih besar, sedangkan nasofaring dan orofaring relatif lebih pendek dan sempit. Apabila terjadi peradangan yang disertai demam, maka peradangan menjadi semakin parah, besar, dan cepat.

Tingginya angka penyakit ISPA pada balita, selain disebabkan karena kondisi kesehatan anak secara kongenital dan faktor lingkungan yang tidak sehat, faktor lain yang berpengaruh adalah kurangnya pengetahuan keluarga. Pengetahuan merupakan hasil dari tahu, dan ini terjadi setelah orang melakukan penginderaan terhadap suatu objek tertentu. Penginderaan, penciuman, rasa, dan raba. Ibu yang memiliki pengetahuan yang baik tentang ISPA akan membawa dampak positif bagi kesehatan anak karena resiko kejadian ISPA pada anak dapat dieleminasi seminimal mungkin (Notoadmojo, 2007). Tujuan dari penelitian ini adalah mengetahui hubungan pengetahuan orang tua tentang ISPA dengan kejadian ISPA pada balita di Desa Dawungsari Kecamatan Pegandon Kabupaten Kendal. 


\section{Tinjauan Teoritis}

1. Balita

Menurut Haryatiningsih, 2014 balita adalah anak usia 12-59 bulan. Fase balita sebenarnya melibatkan fase usia bayi (0-1 tahun), toddler (1-3 tahun) dan pra sekolah (3-6 tahun).

2. ISPA (Infeksi Saluran Pernafasan Akut)

Infeksi Saluran Pernafasan Akut (ISPA) adalah penyakit infeksi pada saluran pernafasan atas maupun bawah yang disebabkan oleh bakteri atau virus kedalam organ saluran pernafasan selama kurang empat belas hari (Kemenkes RI, 2013).

3. Pengetahuan

Pengetahuan (knowledge) adalah hasil tahu dari manusia yang sekedar menjawab pertanyaan "What". Pengetahuan merupakan hasil dari tahu, dan ini terjadi setelah orang melakukan penginderaan terhadap suatu objek tertentu.Penginderaan, penciuman, rasa, dan raba. Pengetahuan atau kognitif merupakan domain yang sangat penting dalam membentuk tindakan seseorang (Mubarak, 2007).

\section{Metode Penelitian}

Jenis atau rancangan penelitian ini adalah deskriptif korelatif dengan metode penelitian menggunakan penelitian cross-secctional. Sampel pada penelitian ini adalah 72 orang tua yang memiliki balita usia 1-5 tahun di Desa Dawung Sari dengan teknik pengambilan sampel purposive sampling. Alat pengumpulan data menggunakan kuesioner. Jumlah pertanyaan kuesioner tentang kejadian ISPA terdiri dari kuesioner untuk kejadian ISPA pada balita berisi 1 pertanyaan dengan jawaban i ya/ tidak. Pertanyaan tentang pengetahuan ISPA terdiri dari 20 pertanyaan multiple choice dengan 16 pertanyaan favorable dan 4 pertanyaan unfavorable. Skor jawaban untuk pertanyaan favourable "ya"= 1 dan "Tidak"=0, sedangkan untuk pertanyaan unfavorable "ya"= 0 dan "tidak"=1. pertanyaan dengan pilihan jawaban ya dan tidak. Analisis data penelitian menggunakan Uji Chi Square. 


\section{Hasil Penelitian}

1. Karakteristik responden

Tabel 1 Karakteristik responden

\begin{tabular}{|c|c|c|}
\hline Karaktersiktik & Minimal & Maksimal \\
\hline Umur orang tua & 19 tahun & 45 tahun \\
\hline Jenis Kelamin Orang tua & Frekuensi (n) & Persentase $(\%)$ \\
\hline Perempuan & 71 & 98,6 \\
\hline Laki-laki & 1 & 1,4 \\
\hline Pendidikan orang tua & Frekuensi (n) & Persentase $(\%)$ \\
\hline SD & 9 & 12,5 \\
\hline SMP & 26 & 36,1 \\
\hline SMA & 31 & 43,1 \\
\hline D3 & 2 & 2,8 \\
\hline S1 & 4 & 5,6 \\
\hline Pekerjaan orang tua & Frekuensi (n) & Persentase $(\%)$ \\
\hline Bekerja & 15 & $20,8 \%$ \\
\hline Tidak bekerja & 57 & $79,2 \%$ \\
\hline Pendapatan keluarga & Frekuensi (n) & Persentase $(\%)$ \\
\hline Kurang & 13 & 18,1 \\
\hline Baik & 59 & 81,9 \\
\hline Hubungan dengan balita & Frekuensi (n) & Persentase $(\%)$ \\
\hline Ibu Kandung & 71 & 98,6 \\
\hline Ayah Kandung & 1 & 1,4 \\
\hline Jenis Kelamin Balita & Frekuensi (n) & Persentase $(\%)$ \\
\hline Perempuan & 37 & 51,4 \\
\hline Laki-laki & 35 & 48,6 \\
\hline Status Gizi Balita & Frekuensi (n) & Persentase $(\%)$ \\
\hline \multicolumn{3}{|l|}{ Status Gizi (BB/U) } \\
\hline Kurang & 7 & 9,7 \\
\hline Baik & 65 & 90,3 \\
\hline \multicolumn{3}{|l|}{ Status Gizi (PB/U) } \\
\hline Pendek & 8 & 11,1 \\
\hline Normal & 53 & 73,6 \\
\hline Tinggi & 11 & 15,3 \\
\hline \multicolumn{3}{|l|}{ Status Gizi (BB/TB) } \\
\hline Kurus & 11 & 15,3 \\
\hline Normal & 59 & 81,9 \\
\hline Gemuk & 2 & 2,8 \\
\hline
\end{tabular}

Tabel 1 menunjukkan bahwa karakteristik responden di Desa Dawungsari Kecamatan Pegandon Kabupaten Kendal sebagian besar responden berumur rata-rata berumur 30,78 
tahun, berjenis kelamin perempuan sebanyak 71 responden $(98,6 \%)$, pendidikan SMA sebanyak 31 responden $(43,1 \%)$, pekerjaan orang tua IRT sebanyak 57 responden $(79,2 \%)$, pendapatan keluarga baik sebanyak 59 responden $(81,9 \%)$, hubungan dengan balita adalah ibu kandung sebanyak 71 responden $(98,6 \%)$, status gizi balita sebagian besar status gizi baik $90,3 \%$.

\section{Analisa Univariat}

Tabel 2 Pengetahuan ISPA

\begin{tabular}{lcc}
\hline Pengetahuan orang tua tentang & Frekuensi (n) & Persentase (\%) \\
ISPA & & 45,8 \\
\hline Baik & 33 & 27,8 \\
Cukup & 20 & 26,4 \\
Kurang & 19 & 100,0 \\
\hline Total & 72 & \\
\hline
\end{tabular}

Tabel 2 menunjukkan bahwa pengetahuan orang tua tentang ISPA di Desa Dawungsari Kecamatan Pegandon Kabupaten Kendal sebagian besar baik yaitu sebanyak 33 (45,8\%) responden.

Tabel 3 Kejadian ISPA

\begin{tabular}{lcc}
\hline Kejadian ISPA & Frekuensi (n) & Persentase (\%) \\
\hline ISPA & 36 & 50,0 \\
Tidak ISPA & 36 & 50,0 \\
\hline Total & 72 & 100,0 \\
\hline
\end{tabular}

Tabel 3 menunjukkan bahwa kejadian ISPA di Desa Dawungsari Kecamatan Pegandon Kabupaten Kendal sebagian ISPA dan sebagian tidak ISPA yaitu sebanyak $36(50,0 \%)$ responden.

\section{Analisa Bivariat}

Tabel 4 Hubungan pengetahuan orang tua tentang ISPA dengan kejadian ISPA pada balita di Desa Dawungsari Kecamatan Pegandon Kabupaten Kendal, Januari 2018 (n=72)

\begin{tabular}{lccccccc}
\hline & \multicolumn{4}{c}{ Kejadian ISPA } & \multicolumn{2}{c}{ Total } & \multirow{2}{*}{ P } \\
\cline { 2 - 7 } Pengetahuan ISPA & \multicolumn{2}{c}{ ISPA } & Tidak ISPA & \multicolumn{2}{c}{ Value } \\
\cline { 2 - 7 } & $\mathrm{N}$ & $\%$ & $\mathrm{n}$ & $\%$ & $\mathrm{n}$ & $\%$ & \\
\hline Baik & 13 & 39,4 & 20 & 60,6 & 33 & 45,8 & 0,031 \\
Cukup & 15 & 75,0 & 5 & 25,0 & 20 & 27,8 & \\
Kurang & 8 & 42,1 & 11 & 57,9 & 19 & 26,4 & \\
\hline Total & 36 & 50,0 & 36 & 50,0 & 72 & 100,0 & \\
\hline
\end{tabular}


Tabel 4 menunjukkan bahwa dari $33(45,8 \%)$ responden yang memiliki pengetahuan baik tentang ISPA, sebagian besar tidak mengalami kejadian ISPA yaitu sebanyak 20 responden $(60,6 \%)$ dan sebagian kecil yang mengalami kejadian ISPA yaitu sebanyak 13 responden $(39,4 \%)$. Responden yang pengetahuan cukup sebanyak 20 responden $(27,8 \%), 15$ responden $(75,0 \%)$ diantaranya mengalami kejadian ISPA dan 5 responden $(25,0 \%)$ tidak mengalami kejadian ISPA. Sementara responden yang pengetahuan tentang ISPA kurang sebanyak 19 responden $(26,4 \%), 8$ responden $(42,1 \%)$ diantaranya mengalami kejadian ISPA dan 11 responden $(57,9 \%)$ tidak mengalami kejadian ISPA.

Hasil uji memenuhi syarat chi square diperoleh nilai $\rho$ value 0,031 lebih kecil dari pada taraf signifikan 0,05 atau 5\% maka Ha diterima. Sehingga terbukti ada hubungan yang signifikan antara pengetahuan orang tua tentang ISPA dengan kejadian ISPA pada balita di Desa Dawungsari Kecamatan Pegandon Kabupaten Kendal.

\section{Pembahasan}

1. Karakteristik Responden

Karakteristik responden di Desa Dawungsari Kecamatan Pegandon Kabupaten Kendal sebagian besar responden berumur rata-rata berumur 30,78 tahun, berjenis kelamin perempuan sebanyak 71 responden $(98,6 \%)$, pendidikan SMA sebanyak 31 responden $(43,1 \%)$, pekerjaan orang tua IRT sebanyak 57 responden $(79,2 \%)$, pendapatan keluarga baik sebanyak 59 responden $(81,9 \%)$, hubungan dengan balita adalah ibu kandung sebanyak 71 responden $(98,6 \%)$, status gizi balita sebagian besar status gizi baik.

Notoatmojo, 2010 menjelaskan bahwa faktor pemicu yang mempengaruhi pengetahuan yaitu pendidikan, pekerjaan, umur, lingkungan, dan sosial budaya. Makin tinggi pendidikan seseorang makin mudah orang tersebut menerima informasi dan pendidikan ini juga menentukan mudah tidaknya seseorang menyerap dan memahami pengetahuan yang mereka peroleh. Pendapatan merupakan faktor yang paling menentukan kualitas dan kuantitas makanan dan ada hubungan yang erat antara pendapatan dengan gizi. Pendapatan keluarga yang rendah akan mempengaruhi pembelian pangan sehingga menentukan hidangan dalam keluarga tersebut baik dari segi kualitas makanan, jumlah makan dan 
variasi hidangan. Dengan status gizi yang kurang akan menurunkan daya tahan tubuh bayi sehingga bayi lebih mudah terkena penyakit infeksi seperti ISPA (Supariasa, 2012). Hal ini di perkuat dengan penelitian Febrianto (2015) dalam Jurnal Gizi dan Dietetik Indonesia dengan judul Status gizi berhubungan dengan kejadian ISPA pada balita di Wilayah Kerja Puskemas Wonosari I Kabupaten Gunungkidul 2014 menyimpulkan terdapat hubungan antara status gizi dengan kejadian ISPA.

\section{Pengetahuan}

Hasil penelitian menunjukkan bahwa sebagian besar pengetahuan baik yaitu sebanyak 33 $(45,8 \%)$ responden, pengetahuan cukup sebanyak 20 responden $(27,8 \%)$ dan pengetahuan kurang sebanyak 19 responden $(26,4 \%)$. Sebanyak 42 responden $(58,3 \%)$ responden juga menjawab pertanyaan salah mengenai asap rokok tidak dapat menimbulkan batuk pilek. Jika hal ini dibiarkan maka akan mengakibatkan penyakit ISPA pada balita. Paparan yang terus-menerus akan menimbulkan gangguan pernapasan terutama memperberat timbulnya ISPA. Semakin banyak rokok yang dihisap oleh keluarga maka semakin besar memberikan risiko terhadap kejadian ISPA dengan kata lain anak yang orang tuanya merokok akan mudah menderita penyakit gangguan pernafasan.

Semakin tinggi pendidikan seseorang semakin mudah pula mereka menerima informasi, dan pada akhirnya makin banyak pula pengetahuan yang dimilikinya. Informasi yang diperoleh baik dari pendidikan formal maupun non formal dapat memberikan pengaruh jangka pendek (immediate impact) sehingga menghasilkan perubahan atau peningkatan pengetahuan. Usia juga mempengaruhi terhadap daya tangkap dan pola pikir seseorang. Semakin bertambah usia akan semakin berkembang pula daya tangkap dan pola pikirnya, sehingga pengetahuan yang diperolehnya semakin membaik (Notoadmojo, 2010).

Terdapat $26,4 \%$ pengetahuan orang tua tentang ISPA kategori kurang. Hal ini disebabkan karena masih banyak orang tua balita yang pendidikannya rendah dan kurangnya mendapatkan informasi mengenai ISPA. Selain itu, hal ini terjadi karena orang tua belum memahami tentang pengertian ISPA, penyebab ISPA, faktor resiko ISPA, tanda dan gejala ISPA, penatalaksanaan ISPA, komplikasi ISPA dan pencegahan ISPA. Pengetahuan orang tua baru sebatas mengetahui belum pada tahap memahami. 


\section{Kejadian ISPA}

ISPA banyak terjadi pada responden yang memiliki pengetahuan rendah. Pengetahuan yang rendah tersebut di pengaruhi oleh kurangnya informasi dan penyuluhan yang diperoleh responden tentang kejadian penyakit ISPA pada balita yang menyebabkan kejadian penyakit ISPA meningkat. Tingginya angka penyakit ISPA pada balita, selain sering disebabkan karena kondisi kesehatan anak secara kongenital dan faktor lingkungan yang tidak sehat. Faktor lain yang berpengaruh adalah kurangnya pengetahuan dan kemampuan keluarga melaksanakan fungsi perawatan kesehatan keluarga di rumah, sehingga keluarga tidak mampu mengenal permasalahan kesehatan secara dini, dan bagaimana melakukan perawatannya di rumah dengan tepat agar tidak terjadi tingkat keparahan bahkan kematian.

4. Hubungan pengetahuan orang tua tentang ISPA dengan kejadian ISPA pada balita

Hasil penelitian menunjukkan bahwa ada hubungan yang signifikan antara pengetahuan orang tua tentang ISPA dengan kejadian ISPA pada balita. Responden yang memiliki pengetahuan baik tentang ISPA, sebagian besar tidak mengalami kejadian ISPA yaitu sebanyak 20 responden (60,6\%). Responden yang pengetahuan cukup tentang ISPA sebanyak 15 responden $(75,0 \%)$ diantaranya mengalami kejadian ISPA. Sementara responden yang pengetahuan tentang ISPA kurang 11 responden $(57,9 \%)$ tidak mengalami kejadian ISPA. Hal ini dapat dikatakan bahwa semakin baik pengetahuaan orang tua tentang ISPA maka semakin tidak mengalami ISPA.

Pengetahuan orang tua tentang penyakit ISPA merupakan modal utama untuk terbentuknya kebiasaan yang baik demi kualitas kesehatan anak. Pengetahuan atau kognitif merupakan domain yang sangat Penting untuk terbentuknya tindakan seseorang (over behavior). Didasari oleh pengetahuan, kesadaran dan sikap yang positif akan berlangsung lama dan bersifat permanen, ibu yang memiliki pengetahuan yang baik tentang ISPA diharapkan akan membawa dampak positif bagi kesehatan anak karena resiko kejadian ISPA pada anak dapat dieleminasi seminimal mungkin (Soekidjo, 2007).

Terdapat 39,4\% responden yang memiliki pengetahuan baik tentang ISPA namun mengalami kejadian ISPA. Hal ini terjadi karena pengetahuan yang dimiliki oleh responden tidak 
diaplikasikan untuk melakukan pencegahan terhadap ISPA. Sesuai dengan teori yang menyatakan bahwa pengetahuan yang dimiliki seseorang apabila tidak diaplikasikan dengan baik maka tidak akan berdampak positif bagi kesehatan (Soekidjo, 2007).

Penelitian yang sama dengan penelitian yang dilakukan oleh Andriani (2014) dalam Jurnal Keperawatan STIKes Yarsi Sumatra Barat Bukittinggi dengan judul Hubungan Pengetahuan Dan Sikap Ibu terhadap Kejadian Ispa Pada Balita Di Wilayah Kerja Puskesmas Tigo Baleh Bukittinggi Tahun 2014, bahwa ada hubungan yang signifikan antara tingkat pengetahuan ibu dengan upaya perawatan terhadap balita dengan ISPA.

Hal ini juga diperkuat oleh pendapat Notosiswoyo dalam Syahrani, Santoso \& Sayono (2012) dalam jurnal dengan judul Pengaruh Pendidikan Kesehatan tentang ISPA Terhadap Pengetahuan dan Keterampilan Ibu Merawat Balita ISPA di Rumah, bahwa rendahnya tingkat pengetahuan dan keterampilan keluarga terutama ibu menjadi salah satu pemicu terjadinya ISPA pada balita. Sebagian besar keluarga yang mempunyai balita ISPA dirumah adalah ibu yang tidak mengetahui cara mencegah ISPA.

Ketidaktahuan responden tentang kejadian penyakit ISPA juga disebabkan karena rendahnya pendidikan orang tua dari hasil penelitian di dapatkan bahwa pendidikan ibu yang rendah menyebabkan pengetahuan ibu rendah. Penelitian ini diperkuat oleh Wahyuningsih 2015 dalam penelitiannya yang berjudul "Pengetahuan Ibu Tentang Pencegahan Ispa Menurunkan Kejadian Ispa Pada Balita", bahwa pengetahuan ibu yang meningkat maka kejadian ISPA akan menurun hal ini dapat disebabkan karena pengetahuan memberikan informasi pada seseorang dalam melakukan tindakan. Ibu yang memiliki pengetahuan yang baik maka ia akan mempunyai sikap yang baik dalam melakukan pencegahan, sehingga ibu akan mencegah penyakit daripada mengobati.

Pengetahuan ibu yang tinggi dan sikap yang positif masih ada yang ISPA dan sebaliknya pengetahuan yang rendah dan sikap yang rendah tetapi balita tidak menderita ISPA, hal ini disebabkan karena pengalaman pribadi, pengaruh media massa, dan pengaruh orang lain yang dianggap penting di dalam lingkungannya. 
Tiga (3) tiga faktor penyebab orang tua yang balita nya menderita ISPA yang pertama yaitu faktor pemudah dimana faktor ini mencakup pengetahuan dan sikap orang tua dalam menangani kejadian ISPA pada balita, faktor ini menjadi pemicu terhadap perilaku yang menjadi dasar atau motivasi bagi tindakannya akibat tradisi atau kebiasaan, kepercayaan kepada orang lain, tingkat pendidikan dan tingkat sosial ekonomi. Kedua faktor pemungkin yaitu faktor pemicu terhadap perilaku yang memungkinkan suatu tindakan terlaksana. Faktor ini mencakup ketersediaan sarana dan prasarana kesehatan. Ketiga faktor penguat yaitu faktor ini menentukan apakah tindakan kesehatan memperoleh dukungan atau tidak. Faktor ini terwujud dalam bentuk sikap dan perilaku pengasuh orang tua (Wahyu, 2015).

\section{Kesimpulan}

1. Pengetahuan orang tua tentang ISPA sebagian besar baik yaitu sebanyak $33(45,8 \%)$ responden.

2. Kejadian ISPA di Desa Dawungsari Kecamatan Pegandon Kabupaten Kendal sebagian ISPA dan sebagian tidak ISPA yaitu sebanyak $36(50,0 \%)$ responden.

3. Ada hubungan yang signifikan antara pengetahuan orang tua tentang ISPA dengan kejadian ISPA pada balita di Desa Dawungsari Kecamatan Pegandon Kabupaten Kendal dengan nilai $\rho$ value 0,031 .

\section{Saran}

1. Bagi Orang tua

Mengingat masih ada pengetahuan orang tua tentang ISPA kategori kurang baik, maka diharapkan orang tua untuk meningkatkan pengetahuan dan mengaplikasikan tentang kejadian penyakit ISPA pada balita dengan cara membaca banyak buku, majalah dan mencari informasi tentang ISPA melalui internet.

2. Bagi Perawat

Hasil penelitian dapat dijadikan bahan informasi kepada perawat agar bisa dijadikan masukan bagi perencanaan program penanggulangan kejadian ISPA pada balita dengan cara menindaklanjuti dengan memberikan penyuluhan kepada masyarakat. 
3. Bagi Peneliti Selanjutnya

Peneliti selanjutnya disarankan dapat menggunakan hasil penelitian ini sebagai acuan penelitian selanjutnya dengan menggunakan metode atau variabel yang lain untuk referensi penelitian selanjutnya. 


\section{Daftar Pustaka}

Andriani, Marlina. (2014). "Hubungan Pengetahuan Dan Sikap Ibu terhadap Kejadian Ispa Pada Balita Di Wilayah Kerja Puskesmas Tigo Baleh Bukittinggi Tahun 2014.” Jurnal Keperawatan STIKes Yarsi Sumatra Barat Bukittinggi.

Dinas Kesehatan Kabupaten Kendal. (2014). Profil Kesehatan Kabupaten Kendal Tahun 2015. Kendal: Dinas Kesehatan Kabupaten Kendal.

Febrianto W. (2015). "Status gizi berhubungan dengan kejadian ISPA pada balita di Wilayah Kerja Puskemas Wonosari I Kabupaten Gunungkidul 2014." Jurnal Gizi Dan Dietetik Indonesia Vol. 3, No. 2, Mei 2015

Indriani, Dian. (Oktober 2012). Hubungan Tingkat Pengetahuan Ibu Tentang Infeksi Saluran Pernafasan Akut (Ispa) Dengan Perilaku Pencegahan Pada Balita Di Wilayah Kerja Puskesmas Tirto Ii Kabupaten Pekalongan. Surakarta: Universitas Muhammadiyah Surakarta.

Kemenkes RI. (2012). Pedoman Pengendalian Infeksi Saluran Pernafasan Akut.Jakarta: Depkes RI.

Misnadiarly. (2008). Penyakit Infeksi Saluran Napas Pneumonia pada Anak Balita,Dewasa, dan Usia Lanjut. Jakarta: Pustaka Obor Populer.

Mubarak,Wahit Iqbal.(2007). Promosi Kesehatan: Sebuah Pengantar Proses Belajar Mengajar dalam Pendidikan. Yogyakarta: Graha Ilmu.

Notoadmojo, Soekidjo. (2007). Promosi Kesehatan dan Ilmu Perilaku. Jakarta: Rineka Cipta.

Notoadmojo. (2010). Promosi Kesehatan; Teori \& Aplikasi. Jakarta: Rineka Cipta.

Purwandari, Haryatiningsih. (2014). Perkembangan Balita: Deteksi dan Stimulasi Tumbuh kembang Balita. Yogyakarta: Pustaka Pelajar.

Saleh, Abdul Qodir. (2008). Panduan Lengkap Mendeteksi, Memahami, dan Mengatasi Masalahmasalah Kesehatan Pada Anak Secara Medis dan Psikologis. Yogyakarta: DIVA Press.

Supariasa. (2012). Penilaian Status Gizi. Jakarta: Buku Kedokteran EGC

Syahrani, Santono \& Sayoso (2012). Pengaruh Pendidikan Kesehatan tentang ISPA Terhadap Pengetahuan dan Ketrampilan Ibu Merawat Balita ISPA di Rumah. Diakses 18 Januari 2017 dari dari http://ejournal.stikestelogorejo.ac.id/index.php/ilmukperawatan/article.

Wahyuningsih, Aries. (2015). "Pengetahuan Ibu Tentang Pencegahan Ispa Menurunkan Kejadian Ispa Pada Balita.” Jurnal Stikes Vol. 8, No.2, Desember 2015.

WHO. (2007). International Statistical Classification of Diseases and Related Health Problems: Tenth Revision, 10th ed. Geneva: World Health Organisation. 